Michał Widera ${ }^{1}$

Uniwersytet Opolski, Opole, Polska

Wydział Teologiczny

\title{
Dzialalność Zgromadzenia Misjonarzy Świętej Rodziny w Wieluniu
}

\section{Wprowadzenie}

Początki działalności Zgromadzenia Księży Misjonarzy Świętej Rodziny ${ }^{2}$ w Polsce, założonego przez ojca Jana Berthiera³ ${ }^{3}$, sięgają 26 lutego 1921 roku, kiedy to księża Antoni Kuczera i Piotr Zawada oraz brat Stanisław Jakus przybyli do Wielunia (należącego do diecezji kujawsko-kaliskiej, a od 1925 roku do diecezji częstochowskiej) i przejęli znajdujący się tam klasztor poaugustiański.

W dniu 28 lutego 2021 roku, w dawnym klasztorze, który obecnie jest kościołem parafialnym pod wezwaniem Nawiedzenia Najświętszej Maryi Panny

${ }^{1}$ Michał Widera - ks. dr teologii w zakresie historii Kościoła, absolwent Wydziału Teologicznego Uniwersytetu Opolskiego; e-mail: wideramichal@o2.pl. ORCID: 0000-0002-7849-8887.

${ }^{2}$ Pod koniec XIX wieku we Francji doszło do gwałtownego rozwoju zakonów misyjnych. Jednym z nich była wspólnota saletynów, do której należał Jan Berthier - twórca Zgromadzenia Księży Misjonarzy Świętej Rodziny. Kolebką tego zakonu stało się Grave w Holandii. W dniu 28 września 1895 roku oficjalnie rozpoczął on własną działalność, a jego głównym zadaniem stało się głoszenie misji i rekolekcji oraz kształcenie młodzieży do kapłaństwa. Misjonarze Świętej Rodziny. 100 lat w stużbie Bogu i ludziom, oprac. M. Bocian, Otwock-Poznań 1995, s. 33-38.

3 Jan Chrzciciel Berthier (1840-1908) - po wstąpieniu do misjonarzy z La Salette przyjął święcenia kapłańskie. Zajmował się posługą wobec pielgrzymów, redagowaniem kroniki zakonnej i publikacją artykułów na temat objawień maryjnych. Pełnił funkcje wykładowcy i dyrektora Niższego Seminarium Duchownego w Corps i Wyższego Seminarium Duchownego Saletynów w Leuk-Susten w Szwajcarii. Po uzyskaniu zezwolenia Stolicy Apostolskiej założył w Grave w dniu 28 września 1895 roku Zgromadzenie Misjonarzy Świętej Rodziny, które zajmowało się formacją spóźnionych powołań misyjnych. W 1950 roku rozpoczął się jego proces beatyfikacyjny. B. Łoziński, Leksykon zakonów w Polsce, Warszawa 1998, s. 87; P. Krupa, Osoba i życie ks. Jana Berthier, w: „Cor unum et anima una”. Księga Jubileuszowa ku czci księdza Jana Berthier, Zatożyciela Zgromadzenia Misjonarzy Świętej Rodziny z okazji 100-lecia jego śmierci, red. A.J. Sobczyk, Pelplin 2009, s. 219-225. 
i sanktuarium Matki Bożej Pocieszenia, przełożony prowincjonalny, ksiądz Piotr Jacek Krupa, zainaugurował uroczystą Mszą Świętą rok jubileuszowy, trwający do 26 grudnia 2021 roku. Stało się to okazją do przypomnienia pamiętnego przybycia pierwszych księży misjonarzy do Wielunia i powitania ich przez dziekana, księdza Wincentego Przygodzkiego, a także do złożenia pod obrazem Matki Bożej stu róż i przekazania sanktuarium kielicha mszalnego jako wotum wdzięczności za działalność Zgromadzenia Księży Misjonarzy Świętej Rodziny w Wieluniu i dla upamiętnienia obchodów rocznicowych.

Główne uroczystości jubileuszowe odbyły się w dniach 22-24 maja 2021 roku w Górce Klasztornej wraz z sympozjum naukowym, zorganizowanym pod auspicjami Wydziału Teologicznego Uniwersytetu im. Adama Mickiewicza w Poznaniu. W trakcie trzech sesji podjęto między innymi tematykę historyczną, dotyczącą okresu II Rzeczypospolitej i drugiej wojny światowej oraz początków działalności zgromadzenia w Polsce. Znalazło to odniesienie szczególnie w referatach: ks. prof. UAM dr. hab. Bernarda Kołodzieja TChr: Sytuacja społeczno-religijna na ziemiach polskich po zakończeniu I wojny światowej; o. prof. UAM dr. hab. Pawła Zająca OMI: Odradzanie się życia zakonnego w wolnej Ojczyźnie po 1918 r. Przykład Misjonarzy Oblatów Maryi Niepokalanej, ks. dra Piotra Jacka Krupy MSF: Początki Misjonarzy Świętej Rodziny w Polsce, prof. dr. hab. Jana Żaryna: Martyrologia duchowieństwa katolickiego w latach II wojny światowej i ks. Janusza Jezuska MSF: Polscy męczennicy Misjonarze Świętej Rodziny okresu drugiej wojny światowej. ${ }^{4}$ Niniejszy artykuł nie rości sobie praw do uzupełnienia refleksji naukowej, podjętej podczas sympozjum, ale jest przyczynkiem do przedstawienia działalności Zgromadzenia Księży Misjonarzy w Wieluniu w niełatwych czasach budowania nowego ładu społecznego i religijnego w okresie międzywojennym oraz w jeszcze trudniejszym okresie drugiej wojny światowej. Z pewnością głęboka wiara i wzmożona aktywność duszpasterska księży misjonarzy pracujących w powiecie wieluńskim stały się solidnym fundamentem inaugurującym ich stuletni pobyt na ziemiach polskich.

\section{Sytuacja społeczno-religijna w powiecie wieluńskim po zakończeniu pierwszej wojny światowej}

Po zakończeniu pierwszej wojny światowej ludność powiatu wieluńskiego borykała się z wieloma problemami materialnymi. Ze względu na rolniczy charakter

${ }^{4}$ P. Krupa, List ks. prowincjała na rozpoczęcie jubileuszu 100-lecia MSF w Polsce: https:// www.ekai.pl/100-lat-misjonarzy-swietej-rodziny-w-polsce/ [dostęp 09.06.2021]; https://misjona rzemsf.pl/wydarzenia-2021/gorka-klasztorna-obchody-100-lecia-msf-w-polsce-22-24-maja-2021 [dostęp 09.06.2021]. 
omawianych terenów i ich niskie uprzemysłowienie doszło do dużego wzrostu bezrobocia, które stało się jednym z najpoważniejszych wyzwań dla mieszkańców powiatu. Generowało ono nowe trudności związane z brakiem środków do życia i niebezpieczeństwem rozruchów. W pierwszych latach po odzyskaniu niepodległości w Wieluniu chleb podlegał reglamentacji, a wielu mieszkańców domagało się zatrudnienia. Miasto nie posiadało odpowiednich środków na prowadzenie robót publicznych, dlatego praca w wielu przypadkach stała się przywilejem. W tej sytuacji dochodziło do manifestacji i wzrostu niepokojów społecznych. Duże rozdrobnienie gospodarstw rolnych stało się przyczyną napływu ludności z całego powiatu w poszukiwaniu zatrudnienia. Najtrudniejsza była sytuacja materialna rodzin niemających stałego źródła utrzymania od późnej jesieni do końca maja każdego roku. Wówczas spora część mieszkańców Wielunia i okolicy korzystała z pomocy socjalnej, organizowanej przez władze powiatowe i kościelne. Trudne warunki społeczno-gospodarcze uległy jeszcze większemu pogorszeniu z powodu wzrostu inflacji w latach dwudziestych $\mathrm{XX}$ wieku. W związku z tym dochodziło wręcz do masowej emigracji zarobkowej do sąsiednich Niemiec, a w mniejszym stopniu także do Belgii i Francji ${ }^{5}$.

Obok Kościoła katolickiego, w powiecie wieluńskim w okresie międzywojennym zinstytucjonalizowane struktury posiadał: Kościół Ewangelicko-Augsburski ${ }^{6}$, Polski Autokefaliczny Kościół Prawosławny i Żydowski Zwią-

${ }^{5}$ Archiwum Państwowe w Łodzi. Oddział w Sieradzu (dalej: APŁOS), sygn. Akta Miasta Wielunia 84, Protokót posiedzenia Rady Miejskiej z dn. 16 I 1919 r., s. 53; tamże, Protokót posiedzenia Rady Miejskiej z dn. 3 IV 1919 r., s. 62; M. Widera, ,Stowarzyszenie Wychodźców Polskich pod opieka Królowej Korony Polskiej w diecezji częstochowskiej" w parafiach powiatu wieluńskiego, „Studia Teologiczno-Historyczne Śląska Opolskiego” 40 (2020) nr 2, s. 164-172.

${ }^{6}$ Parafia ewangelicko-augsburska w Wieluniu w okresie międzywojennym swoim zasięgiem obejmowała granice całego powiatu wieluńskiego z wyłączeniem gmin: Kuźnica Grabowska i Skrzynki. Należały do niej ponadto trzy gminy z powiatu sieradzkiego (Barczew, Klonowa i Złoczew), a kościoły znajdowały się w następujących miejscowościach: Janów (gm. Skrzynno), Krzeczów (gm. Mierzyce), Marianów (gm. Majaczewice, pow. sieradzki), Wieluń i Wolnica Grabowska (gm. Majaczewice, pow. sieradzki). Główna świątynia parafialna mieściła się w Wieluniu. APŁOS, sygn. Starostwo Powiatowe Wieluńskie (dalej: SPW) 337, s. 6, 8-9; tamże, sygn. SPW 1856, Pismo do Urzędu Wojewódzkiego Wydziat Administracyjny w Łodzi z dn. 19 I 1933 r.

${ }^{7}$ Ośrodki prawosławne w powiecie wieluńskim mieściły się w: Chróścinie, Praszce i Wieluniu, a wierni przynależeli do parafii w Łodzi. APŁOS, sygn. SPW 1844, Pismo Ministerstwa Wyznań Religijnych i Oświecenia Publicznego Nr VI.N.K.1518/31. do Ministerstwa Rolnictwa; Archiwum Państwowe w Łodzi, sygn. Urząd Wojewódzki Łódzki 2532, s. 48, 70; T. Olejnik, Muzeum Ziemi Wieluńskiej. Dzieje. Zbiory. Działalność 1964-1984, Warszawa-Lódź 1989, s. 11; J. Książek, Powiat wieluński w latach 1918-1939, „Rocznik Wieluński” (dalej: RW) 1(2001), s. 120; T. Olejnik, Czasy nowożytne. Praszka w XIX i XX wieku, w: Nad górną Prosna. Monografia Praszki, red. T. Krzemiński, Łódź 1999, s. 316-317; K. Latawiec, Duchowieństwo cerkwi prawosławnych resortu celnego i straży granicznej w Królestwie Polskim w latach 1851-1914, „Res Historica” 37 (2014), s. 213, 221. 
zek Wyznaniowy ${ }^{8}$. Społeczeństwo powiatu w przeważającej części wyznawało religię katolicką. Zdecydowaną mniejszość stanowili Żydzi zgrupowani głównie w siedmiu żydowskich gminach wyznaniowych. Ponadto w tym okresie sukcesywnie zmniejszała się liczba ewangelików, Żydów i innych wyznawców (m.in. prawosławnych) na rzecz coraz większego udziału katolików. W 1938 roku w całym powiecie mieszkało około 219 tysięcy osób tego wyznania (czyli ok. 93,25\% wszystkich mieszkańców), 13794 osób (ok. 5,87\%) było wyznania mojżeszowego, 1970 osób $(0,83 \%)$ - ewangelickiego, a 87 osób $(0,04 \%)$ - prawosławnego?.

Okres zaborów ziem polskich wpłynął negatywnie na religijność wiernych, a z pewnością na zmniejszenie ich udziału w nabożeństwach. Zwrócił na to uwagę biskup Stanisław Zdzitowiecki ${ }^{10}$, gdy w 1921 roku w liście do duchowieństwa i wiernych pisał: „Któż nie widzi, że znacznie ostygła gorąca wiara, zmniejszyła się liczba uczęszczających do sakramentów św.? Wielu zapomina o Bogu i Kościele w dni święte, osłabła zarazem cześć i posłuch dla kapłanów i sług ołtarza"11. Nowa rzeczywistość powojenna postawiła przed duszpasterzami pierwszorzędne zadanie, które polegało na ożywieniu życia religijnego powierzonej ich opiece ludności. Na pierwszy plan wysunęła się kwestia udzielania sakramentów, co mogło stać się fundamentem do dalszej pracy duszpasterskiej, która zwłaszcza od momentu utworzenia diecezji częstochowskiej skupiła się na rozwijaniu organizacji katolickich. Biskup Teodor Kubina ${ }^{12}$ w następujący sposób opisywał religijność mieszkańców powiatu wieluńskiego: „ziemia ta, choć uboga, jest piękna i miła, a lud jej choć prosty i biedny, jednak jest gorliwy i pobożny"'13. Zaangażowanie wiernych wiązało się nie tylko z udziałem w nabożeństwach i przyjmowaniem przez nich sakramentów, ale także z dbałością o miejsca sprawowania kultu. W okresie międzywojennym uroczyście poświęcono kościoły w: Osjakowie (29 VI 1919), Lututowie (15 VI 1927),

\footnotetext{
${ }^{8}$ Wyznawcy judaizmu skupiali się w siedmiu gminach wyznaniowych, znajdujących się w: Bolesławcu, Działoszynie, Lututowie, Osjakowie, Praszce, Wieluniu i Wieruszowie.

${ }^{9}$ M. Widera, Wspólnoty wyznaniowe w powiecie wieluńskim w II Rzeczypospolitej, ,Veritati et Caritati” 12 (2019), s. 661-666, 674-695.

${ }^{10}$ Stanisław Kazimierz Zdzitowiecki (1854-1925) - biskup diecezji kujawsko-kaliskiej w latach 1902-1925. Ksiadz Stanisław Kazimierz Zdzitowiecki, biskup diecezji włocławski, „Kronika Diecezji Włocławskiej” 21 (1927), s. 33-34; W. Frątczak, Zdzitowiecki Stanisław Kazimierz, w: Włocławski Słownik Biograficzny, red. S. Kunikowski, t. I, Włocławek 2004, s. 186-187.

${ }^{11}$ Biskup kujawsko-kaliski do wielebnego duchowieństwa i ludu wiernego, „Kronika Diecezji Kujawsko-Kaliskiej" (dalej: KDKK) 15 (1921) nr 1, s. 1.

12 Teodor Kubina (1880-1951) - biskup diecezji częstochowskiej w latach 1925-1951. K. Krasowski, Biskupi katoliccy II Rzeczypospolitej. Stownik biograficzny, Poznań 1996, s. $133-$ $-139$.

13 T. Kubina, List Pasterski w sprawie III Diecezjalnego Kongresu Eucharystycznego w Wieluniu, „Wiadomości Diecezjalne” (dalej: WD) 6 (1931) nr 2, s. 36.
} 
Przedmościu (15 XII 1927) i Ostrówku (18 VI 1939). Z kolei kaplice benedykowano w Kiełczygłowie i Galewicach. Wiązało się to z powstawaniem nowych parafii, które mogły zapewnić odpowiednią opiekę duszpasterską rosnącej liczbie mieszkańców powiatu. Do 1939 roku w jego granicach erygowano następujące parafie: Chróścin, Czajków, Galewice, Kadłub, Kiełczygłów, Łubnice, Ochędzyn, Ostrówek, Przedmość, Radostów, Radoszewice, Szynkielów (ekspozytura) i Wierzbie ${ }^{14}$.

Poza zwiększającą się liczbą obowiązków parafialnych kapłani podejmowali szeroko pojętą działalność społeczną będącą wówczas bardzo aktualnym zadaniem nie tylko jednoczącym wiernych, ale także wpływającym na budowę nowej państwowości i poprawę warunków materialnych ludności poszerzającej między innymi swoją wiedzę dotyczącą właściwego gospodarowania ziemią ${ }^{15}$. Szerokie spectrum organizacji społecznych przyczyniało się do: zrzeszania się grup zawodowych, rozwijania kultury i oświaty, prowadzenia działalności dobroczynnej, utrwalania więzi międzyludzkich czy rozwijania religijności i patriotyzmu. Szczególne miejsce wśród organizacji społecznych, często inicjowanych i wspieranych przez duchownych, zajmowały stowarzyszenia funkcjonujące pod egidą Ligi, a następnie Akcji Katolickiej. Organizacja ta zrzeszała wiernych z różnych grup wiekowych i aktywizowała ich wokół wspólnych spraw o charakterze społecznym i religijnym ${ }^{16}$. Do podejmowania takiej działalności wymagana była zdecydowanie większa liczba duchownych niż do samej tylko pracy duszpasterskiej, choć w diecezji kujawsko-kaliskiej, a następnie częstochowskiej, i do tego brakowało kapłanów. Proboszczowie parafii powiatu wieluńskiego prosili o przydzielenie wikariuszy i prefektów do szkół, w których religia stała się przedmiotem obowiązkowym. Wpłynęło to z pewnością na ogromną otwartość biskupa Stanisława Zdzitowieckiego wobec zgromadzeń zakonnych, które zgodnie $\mathrm{z}$ oczekiwaniami miały wspomagać kapłanów diecezjalnych w aktywności duszpasterskiej ${ }^{17}$.

${ }^{14}$ Katalog kościołów i duchowieństwa diecezji częstochowskiej 1968, red. L. Sokołowski, W. Patykiewicz, J. Walicki, Częstochowa 1968, s. 90-91, 209, 263, 267-268, 272, 274; Katalog kościołów i duchowieństwa diecezji częstochowskiej 1978, red. J. Związek, Częstochowa 1978, s. 165, 168, 170, 217, 371, 401, 404, 496, 516, 522, 527-528; W. Kujawski, Parafie diecezji włoctawskiej. Okres kujawsko-kaliski 1818-1925, Włocławek 2018, s. 561, 578-579, 590, 599, 613, 616, 654 .

${ }^{15}$ APŁOS, sygn. SPW 276, Wykaz zarejestrowanych stowarzyszeń i zwiqzków w I i II kwartale b.r., s. 2-3; Rozporzadzenia diecezjalne, KDKK 15 (1921) nr 2-3, s. 41.

${ }^{16}$ L.B. Dyczewski, Religijność społeczeństwa polskiego w okresie międzywojennym, „Collectanea Theologica” 42 (1972), s. 35; W. Piwowarski, Formy duszpasterstwa parafialnego w Polsce Odrodzonej (1918-1939), w: Kościót w II Rzeczypospolitej, red. Z. Zieliński, S. Wilk, Lublin 1980, s. 140; W. Frątczak, Kościót rzymskokatolicki we Włocławku w okresie Drugiej Rzeczypospolitej, w: Włocławek. Dzieje miasta, red. J. Staszewski, t. II: Lata 1918-1998, Włocławek 2001, s. 240.

17 Powrót zakonów po wojnie, KDKK 12 (1918) nr 5-6, s. 140. 


\section{Okoliczności powstania domu zakonnego w Wieluniu}

W nowej rzeczywistości politycznej, od 1919 roku, generał holenderskiego Zgromadzenia Misjonarzy Świętej Rodziny - ksiądz Antoni Maria Trampe ${ }^{18}$ poczynił starania o rozszerzenie działalności tej apostolsko-kleryckiej wspólnoty w krajach, z których pochodzili jej członkowie bądź kandydaci. W Polsce starania o utworzenie domu zakonnego zlecono Antoniemu Kuczerze ${ }^{19}$, który po nieudanych próbach podejmowanych na Śląsku (w diecezji wrocławskiej) zgłosił się do Stanisława Zdzitowieckiego. Podczas spotkania, w dniu 10 października 1920 roku, biskup zaproponował objęcie dawnego klasztoru augustiańskiego w Wieluniu. Niestety trudność stanowił fatalny stan budynków, ponieważ nie były one poddawane koniecznym remontom przez czterdzieści lat. Po kasacie zakonu augustianów część zabudowań stała się własnością miasta i została zajęta przez lokatorów. Wielką przychylność okazał wówczas zarząd miejski, który zaoferował przekazanie ich na rzecz zakonu. Ten średniowieczny klasztor, ufundowany przez króla Kazimierza Wielkiego, kilkakrotnie uległ spaleniu. Dużym kultem cieszył się znajdujący się w nim obraz Matki Bożej Pocieszenia, ufundowany w 1640 roku przez przeora augustianów w Krakowie. Przedstawiał Dzieciątko Jezus na kolanach Maryi ubranej w czerwoną suknię i trzymającej w ręku różę. Wizerunek posiadał srebrną sukienkę ozdobioną ornamentem roślinnym ${ }^{20}$.

18 Antoni Maria Trampe MSF - przełożony generalny zgromadzenia w latach 1919-1947. A. Sobczyk, P. Krupa, Ksiądz Antoni Kuczera (1883-1958). Założyciel Polskiej Prowincji Zgromadzenia Misjonarzy Świętej Rodziny, Pelplin 2008, s. 108.

${ }_{19}$ Antoni Kuczera MSF (1883-1958) - urodził się w Grabczoku koło Opola. Przez kilka lat przebywał w Zgromadzeniu Misjonarzy Oblatów w Holandii, a następnie przeniósł się (w 1905) do Zgromadzenia Misjonarzy Świętej Rodziny. W dniu 4 października 1909 roku złożył śluby wieczyste, a w dniu 10 czerwca 1911 roku przyjął święcenia kapłańskie. Następnie głosił misje i rekolekcje, głównie dla emigrantów z Polski. Od 1910 roku wydawał „Posłańca Świętej Rodziny” w języku polskim. Po zakończeniu pierwszej wojny światowej otrzymał zadanie znalezienia domu zakonnego z zamiarem otworzenia w nim szkoły misyjnej. Został przełożonym pierwszego domu księży misjonarzy w Polsce: w Wieluniu. Jego staraniem został utworzony kolejny dom zgromadzenia: w Kazimierzu Biskupim. Od 1922 roku był wizytatorem klasztorów w diecezji włocławskiej. W 1923 roku został rektorem domu zakonnego w Górce Klasztornej. Następnie prowadził działalność duszpasterską i misjonarską. W latach 1928-1932 był prowincjałem zgromadzenia w Polsce. Od 1938 roku został mistrzem nowicjatu w Kruszewie, a następnie prowincjałem prowincji polskiej (w latach 1939-1946) i rektorem w Górce Klasztornej. A. Sobczyk, P. Krupa, Ksiądz Antoni Kuczera, s. 15-24, 53-68.

20 Archiwum Zgromadzenia Misjonarzy Świętej Rodziny w Poznaniu (dalej: AMSFP), brak sygn., F. Napierała, Zgromadzenie Księży Misjonarzy św. Rodziny w Polsce, s. 1; tamże, brak sygn., T. Dusza, 50 lat działalności Polskiej Prowincji Misjonarzy św. Rodziny, Świder 1984, s. 29; tamże, brak sygn., Teczka XVII-16 Wieluń 1938-1962. Krótki opis Kościoła Księży Misjonarzy św. Rodziny; Wieluń. Kolebka polskiej prowincji, „Posłaniec Świętej Rodziny” 22 (1931) nr 3, 
Wobec dużej przychylności zarówno władz diecezjalnych jak i miejskich Antoni Kuczera powiadomił zarząd generalny zgromadzenia o możliwości utworzenia w Wieluniu szkoły misyjnej, a następnie otrzymał pozwolenie na prowadzenie dalszych pertraktacji. Miała wtedy miejsce wymiana korespondencji pomiędzy Stanisławem Zdzitowieckim, a prowincjałem augustianów w Krakowie - ojcem Andrzejem Styłą ${ }^{21}$. Okazało się, że zgodnie z prawem kościelnym i konstytucjami zakonu jedyną kompetentną osobą do wydania pozwolenia na przekazanie klasztoru był przebywający w Rzymie generał. W związku z tym biskup skierował pismo do Kongregacji do spraw Zakonnych. Po rozmowie Antoniego Kuczery z prowincjałem augustianów pojawiły się u niego wątpliwości dotyczące ewentualnych roszczeń, które mogłyby nastąpić po podjęciu koniecznego remontu bez prawnego uregulowania kwestii własności klasztoru. Biskup zapewnił jednak, że należy niezwłocznie erygować dom zakonny w Wieluniu, „a w międzyczasie załatwi się sprawy urzędowe"22. Następnie Stanisław Zdzitowiecki oficjalnie przekazał klasztor poaugustiański księżom misjonarzom, którzy - po dokonaniu koniecznych inwestycji - zobowiązali się do zorganizowania w nim szkoły dla młodzieży. Antoni Kuczera prosił o przyśpieszenie nominacji dla dotychczasowego rektora - księdza Jana Osmelaka ${ }^{23}$ (kapłana diecezjalnego) i konsultował się z miejscowym dziekanem w sprawie uroczystego przejęcia klasztoru ${ }^{24}$.

Od dnia 21 stycznia 1921 roku Stanisław Jakus rozpoczął przygotowywanie pomieszczeń dla mających przybyć wkrótce zakonników. W dniu 26 lutego 1921 roku Antoni Kuczera, Piotr Zawada ${ }^{25}$ i Stanisław Jakus przybyli kolejką

s. 42; W. Patykiewicz, E. Banaszkiewicz, Obraz Matki Bożej Pocieszenia w kolegiacie wieluńskiej, „Częstochowskie Wiadomości Diecezjalne” (dalej: CzWD) 45 (1971) nr 4-6, s. 107-115; A. Sobczyk, P. Krupa, W kręgu duchowości świętorodzinnej, Pelplin 2007, s. 180.

${ }^{21}$ Andrzej Styła OSA - przeor konwentu augustianów w Krakowie i komisarz prowincjalski (w latach 1913-1925). G. Uth, Szkic historyczno-biograficzny Zakonu Augustiańskiego w Polsce, Kraków 1930, s. 230-231.

${ }^{22}$ Po wielomiesięcznej wymianie korespondencji augustianie zrzekli się roszczeń do klasztoru w Wieluniu na rzecz Zgromadzenia Misjonarzy Świętej Rodziny po przekazaniu rekompensaty finansowej w wysokości 400 tysięcy marek polskich. Dopiero w dniu 27 września 1935 roku udało się uregulować sprawę własności klasztoru w świetle prawa państwowego, a następnie dokonano wpisu do ksiąg wieczystych. Odtąd zgromadzenie stało się pełnoprawnym jego właścicielem.

${ }^{23}$ Jan Osmelak (1884-1956) - pochodził z Janowa. Po święceniach kapłańskich w 1907 roku był między innymi prefektem w Wieluniu od 1916 roku, a od 1919 roku rektorem kościoła poaugustiańskiego w Wieluniu. W latach 1921-1930 pełnił funkcję administratora w Konopnicy. K. Kęsik, Kościót katolicki w powiecie wieluńskim w czasie I wojny światowej, Opole 2020, s. 456-458.

${ }^{24}$ AMSFP, brak sygn., T. Dusza, 50 lat działalności Polskiej Prowincji Misjonarzy św. Rodziny, s. 29-46.

${ }^{25}$ Piotr Zawada MSF (1889-1939) - pochodził ze wsi Wróblin koło Opola. W wieku kilkunastu lat zgłosił się do domu Zgromadzenia Księży Misjonarzy Świętej Rodziny w Grave w Holandii. W Nieuwkerk ukończył studia filozoficzno-teologiczne, a w dniu 15 sierpnia 1920 roku otrzymał 
wąskotorową z Praszki do Wielunia. Na dworcu oczekiwali ich: Wincenty Przygodzki ${ }^{26}$ wraz z uczestnikami procesji z kościoła farnego, przedstawiciele zarządu miasta i sami mieszkańcy. Dziekan przekazał misjonarzom klucze do kościoła oraz powitał ich chlebem i solą. Po przejściu do świątyni przemówił z ambony, wskazując na znaczenie działalności misyjnej. Jednocześnie zachęcał wiernych do wspierania nowych zakonników, którzy odtąd zamieszkali w Wieluniu. W odpowiedzi Antoni Kuczera podziękował za liczną obecność zebranych i słowa powitania. $Z$ tej okazji zarząd miasta zaprosił obecnych na uroczysty obiad. Wdzięczność księży misjonarzy została wyrażona również wobec Stanisława Zdzitowieckiego w liście z dnia 4 marca 1921 roku w następujących słowach:

Dnia 1 marca objęliśmy, Misjonarze Świętej Rodziny, klasztor poaugustiański w Wieluniu. Jeśli ten pierwszy zakład synów Świętej Rodziny stanął na ziemi polskiej, to zawdzięczamy jedynie ojcowskiej opiece Waszej Ekscelencji. Bóg zapłać Ci stokrotne za wszystko, Czcigodny Arcypasterzu²7.

\section{Struktura materialna}

Pierwszy rektor klasztoru Antoni Kuczera na początku działalności otrzymał od generała zgromadzenia milion złotych, który przeznaczył na dokonanie koniecznych remontów i zakup mebli. Księża misjonarze spotkali się w Wieluniu z wielką życzliwością i ofiarnością mieszkańców miasta, co stało się kolejną zachętą do podejmowania prac restauracyjnych zabytkowego kompleksu budynków. Dzięki koniecznym inwestycjom i zezwoleniu biskupa na zbieranie ofiar

święcenia kapłańskie. Wraz z Antonim Kuczerą tworzył zręby polskiej prowincji. Pełnił funkcję rektora domów zakonnych w: Wieluniu, Kazimierzu Biskupim, Kruszewie i Bąblinie, a następnie od 1936 roku - prowincjała prowincji polskiej. Po wybuchu drugiej wojny światowej został aresztowany i przewieziony do Paterka koło Nakła. W dniu 12 listopada 1939 roku został rozstrzelany. AMSFP, brak sygn., F. Napierała, Zgromadzenie Księży Misjonarzy św. Rodziny w Polsce, s. 107.

${ }^{26}$ Wincenty Przygodzki (1870-1947) - pochodził z Ręczna. Po święceniach kapłańskich we Włocławku (1893) pracował jako wikariusz i proboszcz między innymi w Wieluniu (w latach 1918-1939). W latach 1915-1939 był dziekanem wieluńskim. Rozwinął szeroką działalność społeczną i polityczną, angażował się niemal we wszystkie społeczne przedsięwzięcia wielunian. W 1939 roku został aresztowany przez Niemców i osadzony w obozie w Radogoszczu, a po zwolnieniu udał się do Częstochowy, gdzie zmarł. J. Związek, Przygodzki Wincenty, w: Polski Stownik Biograficzny, red. E. Rostworowski, t. 29, Wrocław 1971, s. 163-164.

${ }_{27}$ AMSFP, brak sygn., F. Napierała, Zgromadzenie Księży Misjonarzy św. Rodziny w Polsce, s. 3; tamże, brak sygn., T. Dusza, 50 lat działalności Polskiej Prowincji Misjonarzy św. Rodziny, s. 64-65. 
na remont kościoła udało się poprawić stan materialny zabudowań klasztornych. W 1922 roku zakonnicy przeprowadzili pod kierunkiem konserwatora restaurację klasztoru systemem gospodarczym. Zostały usunięte prowizoryczne ściany na krużgankach i w celach. Zlikwidowano przeróbki, które zostały dokonane po kasacie konwentu augustianów przez rząd rosyjski. W toku prac udało się przywrócić klasztorowi dawny wygląd i pierwotne cechy architektoniczne, charakterystyczne dla budynków augustiańskich. Koszty restauracji zostały pokryte przez księży misjonarzy i z dobrowolnych ofiar bez żadnej pomocy rządu i władz samorządowych. Jednocześnie udało się $\mathrm{w}$ tym roku wyremontować i przygotować do celów mieszkalnych i edukacyjnych następne pomieszczenia, co umożliwiło przyjęcie większej liczby uczniów do szkoły misyjnej ${ }^{28}$.

W 1925 roku, w okresie wakacyjnym, przeprowadzono kolejny remont klasztoru. Wówczas wymieniono pokrycia dachowe, a strych zaadaptowano na mieszkania dla uczniów. Wymieniono także 103 okna i otynkowano budynki. Do pokrycia kosztów wykonanych prac przyczyniły się zyski z zorganizowanej loterii fantowej, z której dochód wyniósł 2,5 tysięcy złotych. Na pytanie generała Antoniego Marii Trampego o środki na powyższe inwestycje, ksiądz Józef Drzazga odpowiedział: „Jak to się dzieje, że to się wszystko robi bez zaciągania długów, nie wiem? Z pewnością Boża Opatrzność mocno nas wzięła w swoje objęcia"29. Zadziwiać może fakt, że jeszcze w 1923 roku brakowało w klasztorze pieniędzy nawet na znaczki pocztowe. $Z$ tego powodu stosy listów przez kilka tygodni czekały na wysłanie. Wraz z rozwojem materialnym klasztoru wzrastała jednocześnie liczba wiernych uczestniczących w praktykach religijnych i wpływy z dobrowolnych ofiar. Dzięki temu w 1926 roku założono instalacje: wodociągową i kanalizacyjną oraz urządzono w klasztorze toalety i umywalnie. Połowę dachu kościoła pokryto blachą cynkową, a w jego wnętrzu położono nową posadzkę terakotową oraz pomalowano ściany i ołtarze. W kolejnym roku udało się zakupić stacje drogi krzyżowej, a w 1930 roku w całym klasztorze zamontowano instalację elektryczną. Misjonarze, którzy byli oddani swej pracy i troszczyli się o jak najlepszy stan budowli kościelnych, cieszyli się ogromną życzliwością mieszkańców powiatu wieluńskiego. Świadczyło o tym przekazanie w 1937 roku na rzecz polskiej prowincji misjonarzy darowizny w postaci gospodarstwa rolnego w Raczynie ${ }^{30}$.

${ }_{28}$ Tamże, s. 67, 74, 76; Sprawozdanie z działalności Konserwatora Województwa Lódzkiego od dnia 1 stycznia do dnia 30 XII 1922 r., KDKK 17 (1923) nr 11, s. 469-470.

29 Józef Drzazga MSF - prowincjał Zgromadzenia Misjonarzy Świętej Rodziny w Polsce w latach 1931-1936. A. Sobczyk, P. Krupa, W kręgu duchowości świętorodzinnej, s. 238.

${ }^{30}$ AMSFP, brak sygn., F. Napierała, Zgromadzenie Księży Misjonarzy św. Rodziny w Polsce, s. 8; tamże, brak sygn., T. Dusza, 50 lat działalności Polskiej Prowincji Misjonarzy św. Rodziny, s. 105, 122-123; 125, 168, 190, 220; tamże, brak sygn., Teczka XVII-16 Wieluń 1938-1962. Protokót Nr. Spr. 78/45; tamże, Wypis z aktu sporządzonego przed Notariuszem w Wieluniu Wacławem 
Starania księży misjonarzy i wiernych z powiatu wieluńskiego o przywrócenie dawnego blasku zabytkowemu klasztorowi zostały całkowicie zaprzepaszczone po wybuchu drugiej wojny światowej, gdy kościół podczas ataku bombowego uległ zniszczeniu w $25 \%$, gmach klasztorny - w około $75 \%$, a zabudowania gospodarcze spłonęły doszczętnie wraz z żywym inwentarzem. Łącznie straty z tego tytuły wyniosły około 380 tysięcy złotych zgodnie $\mathrm{z}$ wartością waluty na dzień 31 sierpnia 1939 roku. Ponadto z klasztoru wywieziono szaty i naczynia liturgiczne (o wartości ok. 120 tys. zł), wyposażenie biblioteki i muzeum, a także zniszczono wyposażenie kościoła, które było warte około 150 tysięcy złotych. Ponadto w czasie wojny kościół został zdesakralizowany poprzez urządzenie w nim obozu przejściowego dla Żydów, a następnie magazynu zbożowego (w latach 1943-1945) ${ }^{31}$.

\section{Aktywność duszpasterska}

Księża misjonarze po przybyciu do Wielunia bezzwłocznie podjęli pracę duszpasterską w nowym miejscu pobytu. Już od lutego 1921 roku Antoni Kuczera rozpoczął przygotowania do misji, które odbyły się w kościele w dniu 6 marca 1921 roku. Codziennie wygłaszano trzy nauki. Po dwóch dniach do klasztoru przybył generał Antoni Maria Trampe i ksiądz Franciszek Rogosz ${ }^{32}$, który również angażował się w prowadzenie konferencji. Jego talent kaznodziejski wywołał głębokie wzruszenie u słuchaczy. W trakcie ośmiodniowych misji kościół był stale wypełniony wiernymi. Wyspowiadano około 5 tysięcy. mieszkańców Wielunia. Niekiedy udzielano Komunii świętej do godziny dwudziestej przy obowiązującym wówczas od północy poście eucharystycznym. Na zakończenie misji generał pobłogosławił Najświętszym Sakramentem poszczególne stany wiernych ${ }^{33}$.

Pierwszym rektorem klasztoru został Antoni Kuczera. Do pomocy zostali przydzieleni mu bracia Stanisław i Ignacy oraz uczeń Stanisław Łukaszczyk ${ }^{34}$. Księża

Różyckim w roku 1945 z dn. 16 VIII 1945 r; Wieluń. Kolebka polskiej prowincji, „Posłaniec Świętej Rodziny" 22 (1931) nr 3, s. 42.

${ }^{31}$ AMSFP, brak sygn., J. Gawrych, Kronika Księży Misjonarzy Świętej Rodziny od r. 1935 do 1945, s. 12-13.

${ }^{32}$ Franciszek Rogosz MSF (ur. 2 XI 1888) - pochodził z Urbanowic na Górnym Śląsku. W dniu 18 kwietnia 1907 roku wstąpił do Zgromadzenia Księży Misjonarzy. Po złożeniu ślubów wieczystych (4 X 1913), w dniu 16 marca 1918 roku, przyjął święcenia kapłańskie. Pracował w duszpasterstwie w okręgu Nadrenia-Westfalia i w Polsce jako nauczyciel w szkole w Wieluniu. AMSFP, brak sygn., F. Napierała, Zgromadzenie Księży Misjonarzy św. Rodziny w Polsce, s. 104.

${ }_{33}$ Tamże, brak sygn., T. Dusza, 50 lat działalności Polskiej Prowincji Misjonarzy św. Rodziny, s. 66; Misjonarze Świętej Rodziny, s. 63.

${ }^{34}$ Stanisław Łukaszczyk MSF (ur. 1890) - święcenia kapłańskie przyjął w 1932 roku. Od 1937 roku przebywał w domu zakonnym w Kazimierzu Biskupim. Rocznik diecezji włocławskiej 1938, Włocławek 1938, s. 278. 
misjonarze spotkali się w Wieluniu z wielką życzliwością dziekana Wincentego Przygodzkiego i ofiarnością mieszkańców miasta. Było to dodatkową motywacją do rozszerzania pracy duszpasterskiej. Wkrótce księża postarali się o uzyskanie pozwolenia na odprawianie nabożeństwa czerwcowego (na wzór nabożeństwa majowego) i wystawianie Najświętszego Sakramentu w pierwsze piątki miesiąca. W 1922 roku wprowadzono stały dyżur w konfesjonale w dni targowe oraz w Adwencie i Wielkim Poście, rozpoczęto posługiwanie chorym w szpitalu miejskim i okolicznych wioskach, rozwijano kult Matki Bożej Pocieszenia poprzez comiesięczne nabożeństwo, zatroszczono się o przyjęcie nowych członków do Bractwa Matki Bożej Pocieszenia oraz zorganizowano odpust Świętej Rodziny w styczniu każdego roku. Jesienią 1923 roku władza diecezjalna wydała pozwolenie na urządzanie adoracji Najświętszego Sakramentu: w styczniu, marcu i we wrześniu - miesiącach szczególnych nabożeństw ku czci Świętej Rodziny, świętego Józefa i Matki Bożej Saletyńskiej, a także wystawianie Sanctissimum podczas Mszy Świętej i nieszporów w uroczystości i święta Jezusa Chrystusa, Matki Bożej, Świętej Rodziny, świętego Józefa, Matki Bożej Saletyńskiej, podczas dni skupienia w godzinach popołudniowych oraz w każdy piątek po drodze krzyżowej. W 1924 roku ksiądz Jan Górny ${ }^{35}$ został mianowany spowiednikiem kwartalnym sióstr bernardynek, co wpłynęło na rozszerzenie pracy duszpasterskiej misjonarzy w mieście ${ }^{36}$.

Podstawową działalnością tego zgromadzenia było głoszenie rekolekcji. Stanowiło to dobrą odpowiedź na ówczesną sytuację, ponieważ w celu odnowienia życia religijnego wiernych $\mathrm{w}$ okresie międzywojennym organizowano $\mathrm{w}$ wielu parafiach misje parafialne. Były one bardzo istotne w okresie ataków zwolenników bolszewickich na Kościół i niepodległą państwowość oraz miały służyć moralnej poprawie społeczeństwa ${ }^{37}$. Przykładowo w dniach 1-10 lutego 1929 roku w Lututowie pierwsze od niepamiętnych czasów misje wygłosili księża: A. Piasecki, Kazimierz Musiał i Wincenty Zając. Miały one przebieg zbliżony do ćwiczeń duchowych prowadzonych przez innych zakonników. Ponadto misjonarze wygłosili misje między innymi w Praszce w 1935 roku $^{38}$.

35 Jan Górny MSF (1895-1939) - pochodził ze wsi Łuszkowo. Pierwszą profesję zakonną złożył w Grave, gdzie w dniu 20 czerwca 1922 roku otrzymał święcenia kapłańskie. Pełnił funkcję prefekta alumnów w Wieluniu, rektora w Kazimierzu Biskupim i ekonoma prowincjalnego w Górce Klasztornej. Został zamordowany w Paterku koło Nakła. AMSFP, brak sygn., F. Napierała, Zgromadzenie Księży Misjonarzy św. Rodziny w Polsce, Kazimierz Biskupi-Bąblin 1955-1956, s. 108.

${ }^{36}$ Tamże, brak sygn., T. Dusza, 50 lat działalności Polskiej Prowincji Misjonarzy św. Rodziny, s. $67-68,73-74$.

${ }^{37}$ Urzadzanie misji parafialnych, KDKK 13 (1919) nr 1, s. 3; Zapraszanie na misję OO. Jezuitów, KDKK 13 (1919) nr 4, s. 117; O popieraniu misji parafialnych, KDKK 15 (1921) nr 11, s. 287 -288; Zakonnicy do prowadzenia misji parafialnych, KDKK 16 (1922) nr 12, s. 492; W. Pogorzelski, Uwagi o urządzaniu misji parafialnych, KDKK 18 (1924) nr 5, s. 256-259.

${ }^{38}$ Pomimo mrozu parafianie licznie zebrali się, aby powitać misjonarzy i przy śpiewie pieśni Kto się w opiekę wprowadzili ich do kościoła. Następnie odśpiewano hymn Veni Creator i proboszcz 
W działalność duszpasterską angażowali się także nowicjusze, którzy kolportowali w mieście czasopismo wydawane przez zgromadzenie: „Posłaniec Świętej Rodziny" oraz zbierali ofiary i darowizny w postaci zboża i ziemniaków na utrzymanie klasztoru. W 1925 roku wraz z rozwojem materialnym rosła również liczba wiernych uczestniczących w praktykach religijnych. W owym roku udzielono aż 72 tysięcy Komunii świętych ${ }^{39}$ W 1927 roku umieszczono w kościele stacje drogi krzyżowej, które poświęcił gwardian franciszkanów w Wieluniu ojciec Grzegorz Moczygęba ${ }^{40}$. Księża uczestniczyli też w nabożeństwach i spotkaniach o tematyce religijnej w okolicznych parafiach, między innymi w dniu 26 lutego 1927 roku w Rudnikach w akademii z okazji dnia papieskiego wziął udział rektor księży misjonarzy, a w większym gronie księża uczestniczyli w centralnych obchodach uroczystości religijnych dla całego miasta, na przykład z okazji święta Chrystusa Króla ${ }^{41}$.

W latach trzydziestych XX wieku skierowano do klasztoru w Wieluniu dodatkowych członków zgromadzenia, dzięki czemu prowadzono działalność duszpasterską na jeszcze większą skalę. Nadal wielu ludzi spowiadało się w kościele we wtorki, gdy odbywało się targowisko, a także w Adwencie i Wielkim Poście - od wczesnych godzin rannych (5.00-6.00) do godzin 10.00-12.00. W każdym roku rozdzielano około 32 tysięcy Komunii świętych. Nadal też udzielano sakramentów w szpitalu powiatowym i kaplicy braci albertynów. Organizowano specjalne nabożeństwa dla członków Bractwa Pocieszenia Matki Bożej i kolportowano związane z nim broszury.

przemówił do obecnych, oddając parafian pod opiekę misjonarzom na czas misji. W tym dniu odbyło się jeszcze błogosławieństwo Najświętszym Sakramentem i konferencja A. Piaseckiego o znaczeniu misji parafialnych dla poszczególnych stanów. Pomimo niskiej temperatury wierni z uwagą słuchali nauki. Misje obejmowały ćwiczenia duchowe osobno dla kobiet, mężczyzn i młodzieży szkolnej, i kończyły się Komunią świętą generalną każdej grupy parafian. Udzielanie Komunii świętej tłumnie zebranym parafianom wywoływało w nich wzruszenie i umocnienie $\mathrm{w}$ wierze. $\mathrm{W}$ tym czasie śpiewano pieśń $U$ drzwi Twoich stoję Panie. Łącznie rozdano w czasie misji 9 tysięcy Komunii świętych w dniu 10 lutego o godzinie 8.00 nastąpiło zakończenie misji i odprowadzenie duchownych przez parafian do stacji kolejowej w Praszce. Misje w Lututowie, „Niedziela” 4 (1929) nr 10, s. 118; Z misji św. w Praszce, „Niedziela” 10 (1935) nr 22, s. 267-268.

39 AMSFP, brak sygn., Misjonarze Świętej Rodziny, s. 123-124; tamże, brak sygn., T. Dusza, 50 lat działalności Polskiej Prowincji Misjonarzy św. Rodziny, s. 105-106, 116, 122-123, 229; A. Sobczyk, P. Krupa, W kręgu duchowości świętorodzinnej, s. 183.

${ }^{40}$ Grzegorz Paweł Moczygęba OFM (1888-1951) - w 1906 roku wstąpił do Zakonu Braci Mniejszych w Prowincji świętej Jadwigi. Święcenia kapłańskie przyjął w 1913 roku. Od 1931 roku pełnił funkcje prowincjalnego komisarza Trzeciego Zakonu świętego Franciszka i prokuratora misji franciszkańskich. M. Dąbrowski, Grzegorz Moczygęba OFM (1888-1951)-duszpasterz i publicysta franciszkański, „Roczniki Teologiczne” 66 (2019) z. 4, s. 113-125.

${ }^{41}$ Akademia ku czci Papieża Piusa XI w Rudnikach, „Niedziela” 12 (1927), s. 122-123; W Wieluniu, „Niedziela” 47 (1933), s. 566. 
Księża misjonarze włączali się w obchody religijnych wydarzeń ogólnodiecezjalnych i ogólnoświatowych. Zarówno w latach 1925-1926 jak i w latach 1933-1934 obchodzono w całym Kościele jubileusze. W tym czasie wierni mogli uzyskać odpust zupełny za nawiedzenie między innymi kościoła księży misjonarzy. Innym wydarzeniem wyjątkowym dla całej diecezji częstochowskiej był Kongres Eucharystyczny w Wieluniu, który odbył się w dniach 27-29 czerwca 1931 roku. Wówczas, tak jak w pozostałych kościołach miasta, w świątyni misjonarzy odprawiano liczne nabożeństwa i adoracje dla wiernych $\mathrm{z}$ całego powiatu, a także organizowano spotkania dla dzieci z okolicznościowym kazaniem: Eucharystia św. a dziecit ${ }^{42}$.

Domy zakonne podlegały cyklicznym wizytacjom, w tym także klasztor wieluński, który przykładowo w 1936 roku odwiedził w tym celu ksiądz Seweryn Falter - ekonom generalny zgromadzenia, zwracający szczególną uwagę na kwestie finansowe tej wspólnoty. W 1937 roku dom zakonny wizytował prowincjał wraz z księdzem Alojzym Świercem ${ }^{43}$. Na prośbę generała swoją opinię na temat działalności misjonarzy w Wieluniu wyraził Wincenty Przygodzki, który w 1937 roku zapisał:

Zgromadzenie Księży Misjonarzy Świętej Rodziny w Wieluniu w pracy swej około wychowania młodzieży i kapłańskiej oddaje Kościołowi i społeczeństwu katolickiemu znaczne i wydatne usługi. Zachowywanie reguły klasztornej jest przestrzegane, a tak kapłani jak i bracia tego Zgromadzenia swą skromnością, gorliwością oraz trybem swego zakonnego życia budują wiernych. Służą oni również pomocą dla sąsiednich kapłanów w spowiedzi, w prowadzeniu dorocznych rekolekcji i w zastępstwie na wypadek choroby lub wyjazdów proboszczów. Osiedlenie się w Wieluniu Księży Misjonarzy uważać należy za dobroczynne tak dla samego miasta, jak i dla okolicy.

${ }^{42}$ AMSFP, brak sygn., F. Napierała, Zgromadzenie Księży Misjonarzy św. Rodziny w Polsce, s. 9; tamże, brak sygn., T. Dusza, 50 lat działalności Polskiej Prowincji Misjonarzy św. Rodziny, s. 189; tamże, brak sygn., J. Gawrych, Kronika Księży Misjonarzy Świętej Rodziny od r. 1935 do 1945, s. 7; Warunki dostapienia Odpustu Jubileuszowego w diecezji Częstochowskiej, WD 1 (1926), s. 13; Zarządzenia co do jubileuszu w diecezji częstochowskiej, WD 9 (1934), s. 36; Program III Kongresu Eucharystycznego Diecezji Częstochowskiej w Wieluniu w dniach 27, 28 i 29 VI $1931 r .$, „Niedziela” 24 (1931), s. 311.

${ }^{43}$ Alojzy Świerc MSF (1902-1942) - pochodził z Węgier na Śląsku Opolskim. Gimnazjum i nowicjat ukończył w Grave, studia filozoficzne w Górce Klasztornej, a teologiczne w Krakowie. Święcenia kapłańskie otrzymał w dniu 16 maja 1929 roku. Pełnił urząd rektora w Kazimierzu Biskupim i Wieluniu, a następnie pierwszego asystenta prowincji polskiej. Został aresztowany w 1939 roku i wywieziony do Dachau, gdzie zmarł. AMSFP, brak sygn., F. Napierała, Zgromadzenie Księży Misjonarzy św. Rodziny w Polsce, s. 112-113. 
Klasztor odwiedził również biskup Teodor Kubina w dniu 14 maja 1926 roku podczas wizytacji parafii wieluńskiej. Wówczas w przemówieniu do księży i uczniów wskazał na znaczenie rozwijania Akcji Katolickiej i zachęcał młodzież do czynnego zaangażowania w pracę na rzecz Kościoła ${ }^{44}$.

Smutnym wydarzeniem w klasztorze wieluńskim była śmierć księdza Stanisława Groty ${ }^{45} \mathrm{w}$ dniu 26 lutego 1938 roku. Misjonarz ten podczas spełniania posługi duszpasterskiej w szpitalu zakaźnym w Wieluniu zachorował na tyfus. Odczytywano w tym wyjątkowy symbol miłości bliźniego. Zaraziło się od niego kilku uczniów szkoły klasztornej (jeden z nich również zmarł). Niemniej dzięki wprowadzeniu odpowiednich środków sanitarnych udało się uchronić placówkę przed jej zamknięciem ${ }^{46}$.

\section{Działalność wychowawcza i edukacyjna}

Jedną z ważniejszych aktywności księży misjonarzy była działalność wychowawcza i katechizacyjna. Od 27 lutego 1921 roku Piotr Zawada podjął się nauczania religii w wieluńskiej szkole podstawowej po uzyskaniu misji kanonicznej i aprobaty ministerstwa, na podstawie przedłożonych dokumentów potwierdzających kwalifikacje. W owym roku pojawiły się trudności z wysłaniem z Wielunia do Holandii dwunastu kandydatów do zgromadzenia. Było to spowodowane kłopotami finansowymi będącymi pokłosiem kryzysu gospodarczego i dewaluacji złotego. W związku z tym w dniu 1 lipca 1921 roku Antoni Kuczera rozpoczął starania o utworzenie nowicjatu w Wieluniu. Jednym $\mathrm{z}$ powodów prośby o erygowanie oddzielnego nowicjatu dla Polski były ogromne koszty utrzymania kandydatów do zgromadzenia za granicą. Po uzyskaniu przychylnej decyzji generała i Kongregacji do spraw Zakonnych, w dniu 22 sierpnia 1921 roku Rada Generalna Zgromadzenia powzięła uchwałę o założeniu nowicjatu w Wieluniu. W tym roku zgłosiło się do niego już dwóch kandydatów: Józef Nowacki i Władysław Grzegorski. Rektorem domu zakonnego i mistrzem nowicjatu

${ }_{44}$ Tamże, s. 123, 220-221; Program wizyty Pasterskiej w Dekanacie Wieluńskim, „Głos Ziemi Wieluńskiej” (dalej: GZWiel) 19 (1926), s. 6; Wizyta Pasterska J.E. X. Biskupa Kubiny w Dekanacie Wieluńskim, GZWiel 24 (1926), s. 11; W. Przygodzki, Wizyta pasterska J.E. Ks. Biskupa Kubiny w dekanacie wieluńskim, „Niedziela” 17 (1926), s. 11.

45 Stanisław Grota MSF (1909-1938) - pochodził z Pińczyna na Pomorzu. Ukończył gimnazjum biskupie w Pelplinie, a następnie podjął naukę w szkole apostolskiej w Wieluniu. W tym mieście pracował po przyjęciu święceń kapłańskich jako kapelan szpitala powiatowego. Podczas zaopatrywania chorych w sakramenty zachorował na tyfus i zmarł. AMSFP, brak sygn., J. Gawrych, Kronika Księży Misjonarzy Świętej Rodziny od r. 1935 do 1945, s. 9.

46 Tamże, brak sygn., T. Dusza, 50 lat działalności Polskiej Prowincji Misjonarzy św. Rodziny, s. 229; Misjonarze Świętej Rodziny, s. 71. 
został Piotr Zawada. Ponadto od września tego roku utworzono w klasztorze szkołę misyjną - ośmioletnie gimnazjum męskie. Wielkie zasługi w tym zakresie mieli: ksiądz Józef Lipowsek ${ }^{47}$ i nauczyciel miejscowego gimnazjum ${ }^{48}$.

Naukę w nowej szkole podjęli nie tylko uczniowie pochodzący z Wielunia i z całego powiatu, ale nawet ze Śląska. Była to placówka prywatna, niemająca praw państwowych. Uczono w niej następujących przedmiotów: chemii, fizyki, gimnastyki, historii, języków (polskiego, angielskiego, greckiego, francuskiego, łacińskiego i niemieckiego), matematyki, religii i śpiewu. Ze względu na katolicki charakter szkoły w planie zajęć znajdowały się dodatkowe praktyki religijne. Nauczyciele, tak jak w pozostałych placówkach oświatowych, tak i tutaj uczyli kilku przedmiotów. Uczniowie wpłacali roczne czesne w wysokości 500 złotych. Pod względem wieku występowały wśród nich duże rozbieżności. W roku szkolnym 1931/1932 mieli oni od 16 do 26 lat. Poza nauką organizowali okolicznościowe akademie i uczestniczyli w nabożeństwach, zwłaszcza ku czci Matki Bożej. Ponadto wystawiali misteria pasyjne, cieszące się dużą popularnością wśród mieszkańców Wielunia. Uczestniczyli także jako ofiarodawcy w zbiórce na Fundusz Obrony Narodowej. W szkole funkcjonował chór, który występował podczas ważnych uroczystości $\mathrm{w}$ farze wieluńskiej czy wewnętrznych akademii szkolnych. Już w 1921 roku w szkole misyjnej uczyło się 30 uczniów, dlatego Antoni Kuczera podjął starania o utworzenie kolejnego domu zakonnego. Ostatecznie powstał on dzięki życzliwości Stanisława Zdzitowieckiego w Kazimierzu Biskupim. W dniu 4 lipca 1921 roku rozpoczęto w tamtejszym klasztorze prace przygotowawcze do inauguracji działalności po zakończonych wakacjach ${ }^{49}$.

Piotr Zawada, który był prefektem w wieluńskiej szkole podstawowej, jednocześnie pełniąc obowiązki rektora i mistrza nowicjatu, prosił o zwolnienie go z obowiązku nauczania religii już w grudniu 1921 roku. Zgodnie z umową zawartą ze Stanisławem Zdzitowieckim przy przekazywaniu klasztoru, misjonarze byli zobowiązani do zagwarantowania obsady etatu prefekta szkół podstawowych w Wieluniu. W celu spełnienia tego warunku funkcję tę objął kapłan diecezjalny - Franciszek Marekwia ${ }^{50}$, który był przed laty w nowicjacie misjo-

47 Józef Lipowsek był pochodzenia serbskiego. Pomagał Antoniemu Kuczerze w tworzeniu polskiej prowincji zgromadzenia. H. Barnhoorn, Ks. Jan Berthier. Zatożyciel Misjonarzy św. Rodziny 1840-1906, Katowice 1973, s. 195.

${ }^{48}$ AMSFP, brak sygn., T. Dusza, 50 lat działalności Polskiej Prowincji Misjonarzy św. Rodziny, s. $65-66,70$.

${ }^{49}$ Tamże, s. 68-70, 169; tamże, brak sygn., F. Napierała, Zgromadzenie Księży Misjonarzy św. Rodziny w Polsce, s. 5, 9; Wieluń, „Zew Misyjny” 2 (1939) nr 3, s. 59-60; Misjonarze Świętej Rodziny, s. 67-68, 71.

${ }^{50}$ Franciszek Marekwia (1891-1931) - pochodził z Pszczyny. Wstąpił do zgromadzenia, ale po rozpoczęciu nowicjatu przeniósł się do Fryburga Szwajcarskiego, gdzie w 1919 roku przyjął święcenia kapłańskie. Następnie został kapłanem diecezji wrocławskiej, a potem włocławskiej. Od 1922 roku był prefektem szkół w Wieluniu, a od 1924 roku kapelanem sióstr bernardynek. 
narzy w Grave i przebywał wtedy w Pszczynie. Jednocześnie został on kapelanem sióstr bernardynek. Ze względu na rosnącą liczbę obowiązków i zgłaszanie się miejscowych kandydatów do nowicjatu (w lutym 1922 roku) do pomocy rektorowi przybył kleryk Piotr Ramers z Niemiec. W tym czasie wzrastała też liczba uczniów gimnazjum. W 1922 roku przygotowano kolejne pomieszczenia do przyjęcia większej liczby chłopców. We wrześniu 1922 roku było ich już 69 w dwóch klasach (III i IV). Do pomocy w szkole dołączył również Franciszek Rogosz. W nowicjacie nadal pomagał Józef Lipowsek ${ }^{51}$.

Nowicjat odbywali zarówno kandydaci do święceń kapłańskich, jak i aspiranci na braci zakonnych. Pierwsze śluby zakonne złożył w dniu 8 grudnia 1922 roku Władysław Grzegorski, a dzień wcześniej odbyły się obłóczyny przed nowicjatem ośmiu kandydatów na braci. Każdorazowo uroczystości te były poprzedzone ośmiodniowymi rekolekcjami. W 1924 roku śluby zakonne złożyło już czternastu nowicjuszy, a nowicjat rozpoczęło dwóch kandydatów na księży i jeden na brata. Wychowankowie wraz z księżmi uczestniczyli w parafialnych uroczystościach religijnych. W 1923 roku, przed rozpoczęciem nowego roku szkolnego, obchodzono doroczną uroczystość odpustową ku czci Matki Bożej Pocieszenia, następnie uczniowie szkoły i nowicjusze udali się na pielgrzymkę do Częstochowy, w której uczestniczyło około tysiąc osób z Wielunia ${ }^{52}$.

W dniu 12 stycznia 1925 roku Piotra Zawadę zwolniono z funkcji rektora i mistrza nowicjatu w Wieluniu, po czym został on rektorem, a następnie proboszczem w Kazimierzu Biskupim. Na jego miejsce powołano Józefa Drzazgę, a mistrzem nowicjatu mianowano Antoniego Kuczerę. W 1925 roku do pomocy rektorowi zostali skierowani księża: Karol Müller i Jan Górny. Nowicjat został wówczas przeniesiony do Górki Klasztornej, a w Wieluniu prowadzono odtąd, obok działalność duszpasterskiej, wyłącznie szkołę misyjną. W 1926 roku klasztor gościł między innymi generała i biskupa Teodora Kubinę wizytującego parafię wieluńską, który zachęcał młodzież do apostolskiego zaangażowania ${ }^{53}$.

W 1928 roku naukę w szkole rozpoczęło 65 uczniów. Niestety w dniu 25 października 1928 roku zmarł po krótkiej chorobie, w wieku 39 lat, jeden z wychowawców - Franciszek Rogosz. W jego pogrzebie wzięły udział tłumy mieszkańców Wielunia, a żydowscy handlarze - na znak szacunku - zamknęli swoje sklepy na czas przejścia ulicami konduktu pogrzebowego. Miejsce zmarłego

Archiwum Archidiecezji Częstochowskiej im. ks. Walentego Patykiewicza (dalej: AACz), sygn. Teki Patykiewicza AD IV-2, Ks. Franciszek Michat Marekwia 1891-1931, s. 221.

${ }_{51}$ AMSFP, brak sygn., T. Dusza, 50 lat dziatalności Polskiej Prowincji Misjonarzy św. Rodziny, s. $72-74,76$.

${ }^{52}$ Tamże, s. 76, 104, 115.

${ }_{53}$ Tamże, s. 118, 120, 122-123; tamże, brak sygn., F. Napierała, Zgromadzenie Księży Misjonarzy św. Rodziny w Polsce, s. 7-8; A. Sobczyk, P. Krupa, W kręgu duchowości świętorodzinnej, s. 181. 


\section{Tabela 1. Nauczyciele w szkole misyjnej w roku szkolnym 1931/1932}

\begin{tabular}{|l|l|l|l|}
\hline Lp. & \multicolumn{1}{|c|}{ Imię i nazwisko } & \multicolumn{1}{|c|}{ Nauczane przedmioty } & $\begin{array}{c}\text { Tygodniowy } \\
\text { wymiar } \\
\text { godzin }\end{array}$ \\
\hline 1. & ks. Franciszek Deja & j. grecki, j. łaciński & 24 godziny \\
\hline 2. & kl. Zachariasz Krauze MSF1 & j. polski, j. francuski & 24 godziny \\
\hline 3. & Władysław Naruszewicz & chemia, fizyka, j. angielski, matematyka & 26 godzin \\
\hline 4. & ks. Alojzy Świerc & j. niemiecki, gimnastyka, religia, śpiew & 21 godziny \\
\hline
\end{tabular}

Źródło: AMSFP, brak sygn., T. Dusza, 50 lat działalności Polskiej Prowincji Misjonarzy św. Rodziny, s. 168-169.

w klasztorze zajął ksiądz Franciszek Deja ${ }^{54}$, który przybył z Górki Klasztornej. Nauczał języka greckiego i łaciny, jednak w następnym roku szkolnym opuścił dom wieluński. Zmiany personalne wśród księży misjonarzy były częste, o czym świadczyły krótkie pobyty w Wieluniu także innych zakonników ${ }^{55}$.

W 1930 roku rektorem został Alojzy Świerc, z którym współpracowali księża: Jan Górny i Franciszek Kotuła ${ }^{56}$. Rektor jednocześnie zasiadał w zarządzie wieluńskiego Koła Księży Prefektów ${ }^{57}$. W miejscowej szkole przeorganizowano naukę; odtąd mieściły się w niej jedynie klasy: VI-VIII. W roku szkolnym 1930/1931 w szkole przebywało 73 uczniów (klasa VI - 32, klasa VII - 20

${ }^{54}$ Franciszek Deja MSF (ur. 1904) - święcenia kapłańskie przyjął w 1929 roku, w latach 1947-1955 pracował w duszpasterstwie w Limburgii w Holandii i w tym czasie był asystentem generalnym zgromadzenia. A. Nadolny, Polonia holenderska, „Studia Polonijne” 1 (1976), s. 131; https://www.bishop-accountability.org/sites/Patejko_Zbigniew/Polish_Mission_Amsterdam.htm [dostęp 12.06.2021].

${ }_{55}$ AMSFP, brak sygn., T. Dusza, 50 lat działalności Polskiej Prowincji Misjonarzy św. Rodziny, s. 166-167.

${ }^{56}$ Franciszek Kotuła MSF (ur. 1905) - święcenia kapłańskie przyjął w 1929 roku. Od 1935 roku przebywał w domu zakonnym w Kazimierzu Biskupim. Rocznik diecezji włocławskiej 1938, s. 278.

${ }^{57}$ Celem Związku Diecezjalnych Kół Księży Prefektów było na przykład: propagowanie wychowania katolickiego, popieranie interesów instytucji wychowawczych i doskonalenia zawodowego prefektów oraz zabezpieczenie materialne księży uczących religii. Środkami do realizacji tych celów było między innymi: urządzanie kursów i spotkań nauczycielskich i katechetycznych, wydawanie fachowych czasopism i książek, organizowanie odczytów, pogadanek i rekolekcji oraz opiekowanie się stowarzyszeniami młodzieżowymi (sodalicjami, szkolnymi bractwami religijnymi, skautingiem bądź kasami oszczędności). Jedno z kół powstało w 1933 roku w Wieluniu. Jego prezesem w tym czasie był Ferdynand Chmura, a jednym z członków zarządu - Alojzy Świerc. AACz, sygn. Księgi biskupie i kurialne (dalej: KB) 84, s. 173-174; tamże, sygn. KB 89, s. 81; Sprawy diecezjalnego koła księży prefektów, WD 8 (1933) nr 1, s. 9; Statut Związku Diecezjalnych Kót Księży Prefektów, KDKK 14 (1920) nr 3, s. 71-72. 
i klasa VIII - 21), a w kolejnym roku - 54 uczniów. Nauczano wówczas nadal następujące przedmioty: chemię, fizykę, gimnastykę, historię, języki (polski, angielski - fakultatywnie, francuski, grecki, łaciński i niemiecki), matematykę, religię i śpiew.

W celu uzyskania zwolnienia uczniów z obowiązku służby wojskowej kuria diecezjalna w Częstochowie zaświadczyła, że szkoła była niższym seminarium duchownym, które zgodnie z konstytucją nie mogło być objęte poborem ${ }^{58}$. W 1934 roku rektorem został ksiądz Józef Kuchta ${ }^{59}$, a w 1936 roku - ksiądz Witold Drzewiecki ${ }^{60}$.

\section{Doświadczenia drugiej wojny światowej i jej skutki}

Południowo-zachodnia granica powiatu wieluńskiego w II Rzeczypospolitej była jednocześnie granicą państwową. Nagromadzenie znacznych sił wojskowych po niemieckiej stronie świadczyło o rozpoczęciu działań zbrojnych. Wśród ludności panowało przekonanie, że polska obrona wojskowa była gotowa do skutecznego odparcia ewentualnego ataku armii hitlerowskiej. Działania wojenne rozpoczęło zmasowane bombardowanie miasta Wielunia (o godz. 4.40) przez 29 samolotów Luftwaffe, które wystartowały z lotnisk zlokalizowanych pod Opolem. Celem bombardowania stał się szpital powiatowy, mimo że był oznaczony znakami międzynarodowego Czerwonego Krzyża i jako taki nie powinien być obiektem ataku, a także kolegiata wieluńska i inne obiekty religijne, które były chronione prawem międzynarodowym. W wyniku ataku zginęło 1200 mieszkańców Wielunia ${ }^{61}$.

${ }^{58}$ AMSFP, brak sygn., T. Dusza, 50 lat działalności Polskiej Prowincji Misjonarzy św. Rodziny, s. 168.

59 Józef Kuchta MSF - pierwszy rektor domu zakonnego w Wielkim Klinczu w latach 1938-1939. L. Molendowski, Działalność zakonów męskich na Kaszubach w okresie dwudziestolecia międzywojennego, „Acta Cassubiana” 19 (2017), s. 267.

${ }^{60}$ Witold Drzewiecki MSF (1906-1987) - pochodził z Karolowa w województwie płockim. W dniu 23 października 1923 roku wstąpił do domu zgromadzenia w Górce Klasztornej. W dniu 24 czerwca 1934 roku przyjął święcenia kapłańskie w Kruszewie. W latach 1934-1937 pracował w Kazimierzu Biskupim jako katecheta. Od 1937 roku był przełożonym w Wieluniu. W dniu 1 września 1939 roku doznał obrażeń w wyniku zbombardowania Wielunia. Po zakończeniu drugiej wojny światowej pracował między innymi w Wieluniu. AMSFP, brak sygn., Teczka personalna ks. W. Drzewieckiego; tamże, brak sygn. F. Napierała, Zgromadzenie Księży Misjonarzy św. Rodziny w Polsce, s. 10; tamże, T. Dusza, 50 lat działalności Polskiej Prowincji Misjonarzy św. Rodziny, s. 190, 222.

${ }^{61}$ T. Olejnik, Wieluń. Dzieje miasta 1793-1945, Łódź-Wieluń 2008, s. 325-342; tenże, Wieluń polska Guernica, ,das polnische Guernica”, Wieluń 2004, s. 17-25; tenże, Szpital w Wieluniu. Jego dzieje i zniszczenie 1 IX 1939 r.: Pierwsza zbrodnia II wojny światowej, Wieluń 2020. 
W dniu 9 listopada 1939 roku Niemcy aresztowali na terenie tak zwanego Kraju Warty księży pracujących w duszpasterstwie parafialnym. W większości zostali oni jednak zwolnieni, ale siedmiu kapłanów katolickich i pastora ewangelickiego z Wielunia Henryka Wendta przewieziono do więzienia w Radogoszczu (urządzonego w dawnej hali fabrycznej) i przetrzymywano w bardzo trudnych warunkach. Inni duchowni pozostawili za sobą więzienie w dniu 15 stycznia 1940 roku z nakazem opuszczenia Warthegau w ciągu dwóch tygodni. Jednocześnie rozpoczęto ograniczanie działalności religijnej. Na Msze Święte z udziałem wiernych zezwolono tylko w niedziele w godzinach przedpołudniowych, zaś w dni powszednie kapłani mogli odprawiać Msze Święte przy zamkniętych drzwiach kościołów. Skonfiskowano mienie kościelne wraz z dokumentami. Podjęto walkę ze znakami i symbolami religijnymi. W dniu 6 października 1941 roku w godzinach od 3.00 do 5.00 ujęto wszystkich duchownych katolickich $\mathrm{z}$ terenu powiatu i przewieziono ich furmankami do aresztu gestapo w Wieluniu, a następnie do obozu przejściowego w Konstantynowie koło Łodzi. Stamtąd 55 kapłanów z Kraju Warty, należących do diecezji częstochowskiej, w dniu 27 października wywieziono do obozu koncentracyjnego w Dachau ${ }^{62}$. Odtąd w całym powiecie wieluńskim tylko wikariusz z Cieszęcina - Józef Kubica ${ }^{63}$ i proboszcz z Mokrska - Józef Pruchnicki ${ }^{64}$ otrzymali prawo prowadzenia pracy duszpasterskiej. Jedynym otwartym dla polskich katolików kościołem była świą-

${ }^{62}$ M. Michalska, Krzyże żelazne w powiecie wieluńskim, „Polska Sztuka Ludowa” 13 (1959) nr 1-2, s. 54-61; J. Sziling, Polityka okupanta hitlerowskiego wobec Kościoła katolickiego 1939-1945 tzw. Okręgi Rzeszy: Gdańsk-Prusy Zachodnie, Kraj Warty i Regencja Katowicka, Poznań 1970, s. 141-142; J. Związek, Straty diecezji częstochowskiej w okresie okupacji hitlerowskiej 1939-1945, „Częstochowskie Studia Teologiczne” (dalej: CzST) 2 (1974), s. 362; W. Jacewicz, J. Woś, Martyrologium polskiego duchowieństwa rzymskokatolickiego pod okupacja hitlerowska w latach 1939-1945, t. II, Warszawa 1977, s. 131-166; K. Śmigiel, Kościół katolicki w tzw. okręgu Warty 1939-1945, Lublin 1979, s. 125; M. Stażewski, Niemiecka polityka archiwalna na ziemiach polskich włączonych do Rzeszy 1939-1945, Warszawa-Lódź 1991, s. 119-120; J. Związek, Martyrologium kapłanów diecezji częstochowskiej w czasie II wojny światowej, CzST 4 (1976), s. 268-269; tenże, Aresztowanie i męczeństwo kaplanów ziemi wieluńskiej okresie okupacji hitlerowskiej, RW 2 (2002), s. 12-15.

${ }^{63}$ Józef Kubica (1911-1952) - urodził się w rodzinie robotników sezonowych w Essen. W 1929 roku złożył pierwsze śluby w zakonie paulinów. W 1938 roku przeniósł się do diecezji częstochowskiej. W czasie drugiej wojny światowej po aresztowaniu wszystkich kapłanów z powiatu wieluńskiego (6 X 1941) prowadził duszpasterstwo w jedynej w całym powiecie parafii w Rudzie wraz z Józefem Pruchnickim. J. Związek, Ks. Edward Kubik (20 IX 1880-2 XII 1940), „Wiadomości Archidiecezji Częstochowskiej” 80 (2006) nr 1-2, s. 137-138.

${ }^{64}$ Józef Pruchnicki (1894-1963) - pochodził ze Stopnicy. Święcenia kapłańskie przyjął w 1917 roku. Po przejściu do diecezji częstochowskiej w latach 1928-1939 był proboszczem w Mokrsku. W czasie drugiej wojny światowej pełnił posługę duszpasterską na terenie całego powiatu wieluńskiego. Po zakończeniu wojny organizował życie religijne w powiecie (jako dziekan dekanatu wieluńskiego) i działalność edukacyjną w Wieluniu. J. Związek, Ksiądz Józef Pruchnicki i jego czasy (1894-1963), Wieluń 2014. 
tynia w Rudzie, którą czasowo zamykano. Niemieccy katolicy uczęszczali natomiast do kościoła franciszkanów w Wieluniu. Spośród 55 kapłanów z powiatu wieluńskiego, którzy trafili do Dachau, aż 37 poniosło tam śmierć (w tym dwaj późniejsi błogosławieni: Maksymilian Binkiewicz i Ludwig Roch Gietyngier), a tylko 18 doczekało się wyzwolenia obozu przez wojska amerykańskie w dniu 29 kwietnia 1945 roku $^{65}$.

W chwili wybuchu drugiej wojny światowej w klasztorze w Wieluniu przebywali księża: Witold Drzewiecki, Marcin Łochocki ${ }^{66}$, Romuald Szczeciński ${ }^{67}$ oraz bracia: Kazimierz Woźniak i Tomasz Grzelak. Pozostali, czyli księża: Zachariasz Krauze (studiujący w Poznaniu), Mieczysław Skoblewski68, Jan Wiśniewski ${ }^{69}$, Jan Wujek ${ }^{70}$ oraz brat Stanisław Jakus, którzy należeli do klasztoru, aktualnie przebywali na zastępstwach w parafiach bądź na urlopach. Już w dniu 31 sierpnia 1939 roku w Wieluniu bito na alarm, ale był to tylko sygnał próbny. Dlatego też w początkowej fazie bombardowania miasta mieszkańcy klasztoru nie skryli się do schronu. Brat Tomasz Grzelak, któremu wydawało się, że ktoś dzwonił do furty, wyszedł z kuchni, a w tym momencie bomba spadła na pokój rektora i kuchnię. Wówczas wszyscy pośpiesznie udali się do schronu: piwnicy w ogrodzie. Chwilę po tym spadła kolejna bomba, której wybuch spowodował wyrwanie drzwi, za którymi stali Witold Drzewiecki i jego brat Józef

${ }^{65}$ Tenże, Działalność duszpasterska na pograniczu Generalnej Guberni i tzw. ziem wcielonych do III Rzeszy w l. 1939-1945: diecezja częstochowska w okresie okupacji hitlerowskiej, „Saeculum Christianum" 2 (1995) nr 1, s. 54-55; tenże, Wspomnienia ks. Józefa Kubicy (1911-1952) o pracy duszpasterskiej w powiecie wieluńskim w okresie okupacji hitlerowskiej, w: Wspomnienia wojenne 1939-1945 księży diecezji częstochowskiej, oprac. J. Kapuściński, J. Związek, Częstochowa 2012, s. 136-155; P. Kostrzewski, Represje wobec Kościoła częstochowskiego w tzw. Kraju Warty w okresie okupacji niemieckiej (1939-1945), Częstochowa 2015 (mps w bibliotece Uniwersytetu Humanistyczno-Przyrodniczego im. Jana Długosza w Częstochowie), s. 190; tenże, Wojenne losy zakonów i zgromadzeń zakonnych $w$ powiecie wieluńskim $w$ okresie okupacji niemieckiej 1939-1945, RW 16 (2016), s. 197.

${ }^{66}$ Marcin Łochocki MSF (ur. 1905) - święcenia kapłańskie przyjął w 1934 roku, a od 1935 roku przebywał w Wieluniu. Katalog kościołów i duchowieństwa diecezji częstochowskiej na rok 1939, Częstochowa 1939, s. 128.

${ }^{67}$ Romuald Szczeciński (ur. 1909) - święcenia kapłańskie przyjął w 1934 roku, a od 1937 roku przebywał w Wieluniu. Katalog kościołów i duchowieństwa diecezji częstochowskiej na rok 1939, s. 128.

${ }^{68}$ Mieczysław Skoblewski MSF (1908-1940) - pochodził z Inowrocławia. Ukończył gimnazjum misjonarzy w Wieluniu. Pierwsze śluby złożył w 1933 roku, a święcenia kapłańskie przyjął w Bąblinie w 1938 roku. Został zamordowany w obozie koncentracyjnym w Sachsenhausen. AMSFP, brak sygn., F. Napierała, Zgromadzenie Księży Misjonarzy św. Rodziny w Polsce, s. 109-111.

${ }^{69}$ Jan Wiśniewski MSF (ur. 1910) - święcenia kapłańskie przyjął w 1936 roku, a następnie przebywał w Wieluniu. Katalog kościołów i duchowieństwa diecezji częstochowskiej na rok 1939, s. 128.

70 Jan Wujek MSF (ur. 1906) - święcenia kapłańskie przyjął w 1937 roku, a od 1938 roku przebywał w Wieluniu. Katalog kościołów i duchowieństwa diecezji częstochowskiej na rok 1939, s. 128. 
Drzewiecki (ten ostatni zginął na miejscu). Rektor doznał obrażeń głowy, złamania kilku żeber i stracił oko, a Marcin Łochocki lżejszych obrażeń. Płonęło już wtedy całe miasto, w tym północno-zachodnia część klasztoru i znajdujące się w pobliżu zabudowania gospodarcze wraz z żywym inwentarzem. Po drugim ataku bombowym Romuald Szczeciński rozdzielił Najświętszy Sakrament pomiędzy obecnych, aby zapobiec jego profanacji i udzielił sakramentów Witoldowi Drzewieckiemu. Mimo dotkliwych skutków ataku księża misjonarze, zainteresowani losem swoich współbraci, udali się do klasztoru franciszkanów, aby w razie potrzeby pośpieszyć im z pomocą. Wkrótce potem, wskutek nakazu policji, wszyscy wyruszyli w kierunku Osjakowa, a jedynie rektor został przewieziony do rodziny do Łodzi, gdzie spędził resztę wojny ${ }^{71}$.

Po dniu 9 września do Wielunia wrócił Kazimierz Woźniak, który zamieszkał w klasztorze, a następnie księża: Józef Drzazga, który zaangażował się w pracę duszpasterską wraz z Wincentym Przygodzkim, Marcin Łochocki, Romuald Szczeciński, Stanisław Chudy ${ }^{72}$, z Bąblina Franciszek Deja, z Kazimierza Biskupiego Stefan Skupień ${ }^{73}$, który zamieszkał u rodziny w Wieluniu, Marian Łosoś $^{74}$, który podjął funkcję kapelana bernardynek i Jan Wujek, który podjął pracę duszpasterską w Lututowie. W dniu 21 listopada 1939 roku w podobny sposób zaangażował się Franciszek Deja w Naramicach, który pracował później w wieluńskiej landraturze. Z kolei do lutego 1940 roku Franciszek Figura ${ }^{75}$ sprawował duszpasterską opiekę w parafii w Kiełczygłowie ${ }^{76}$.

${ }^{71}$ Archiwum Franciszkanów w Katowicach-Panewnikach, brak sygn., Kronika Klasztoru OO. Franciszkanów, czyli Zakonu Braci Mniejszych w Wieluniu 1920-1950, Wspomnienie br. Bazylego Dworczaka o wybuchu wojny 1939, s. 134; AMSFP, brak sygn., T. Dusza, 50 lat dziatalności Polskiej Prowincji Misjonarzy św. Rodziny, s. 266-268, 272, 277-279; tamże, J. Gawrych, Kronika Księży Misjonarzy Świętej Rodziny od r. 1935 do 1945, s. 9-11.

72 Stanisław Chudy (ur. 1912) - święcenia kapłańskie przyjął w 1936 roku, a następnie przebywał w domu zakonnym w Kazimierzu Biskupim. Rocznik diecezji włocławskiej 1938, s. 278.

${ }^{73}$ Stefan Skupień MSF (ur. 1909) - święcenia kapłańskie przyjął w 1932 roku. Od 1937 roku przebywał w domu zakonnym w Kazimierzu Biskupim. Rocznik diecezji włocławskiej 1938, s. 278.

${ }^{74}$ Marian Łosoś MSF (1910-1978) - pochodził z Buntowa. Po wstąpieniu do zgromadzenia misjonarzy w 1934 roku przyjął święcenia kapłańskie. Pracował w duszpasterstwie między innymi w Wieluniu, a w 1939 roku administrował wieluńską parafią. W 1941 roku został wywieziony do Dachau. Doczekał wyzwolenia obozu. J. Związek, Ks. Losoś Marian (1910-1978), CzWD 53 (1979) nr 4-5, s. 113.

${ }^{75}$ Franciszek Figura MSF (1911-1943) - pochodził z Raciborza. Pierwszą profesję zakonną złożył w 1928 roku, a święcenia kapłańskie przyjął w 1935 roku w Poznaniu. Ukończył prawo na Katolickim Uniwersytecie Lubelskim. W czasie drugiej wojny światowej został przymusowo wcielony do Wehrmachtu i przydzielony do służby sanitarnej. Zginął pod Charkowem. P. Kostrzewski, Wojenne losy zakonów i zgromadzeń zakonnych, s. 194.

${ }^{76}$ Archiwum parafii w Kiełczygłowie, brak sygn., Kronika nowo powstałej parafii Kiełczygłów od 13 X 1924 r., s. 10-13. 
Kościół klasztorny misjonarzy został przeznaczony na tymczasowy obóz dla Żydów, w którym przetrzymywano w sumie około 7 tysięcy osób. Początkowo ze względu na brak świeżego powietrza więźniowie wybili szyby w oknach, a następnie na rozkaz niemieckich żołnierzy spalili w celu ogrzania się wszystkie elementy wyposażenia. Dzięki przezorności księży Józefa Drzazgi i Franciszka Dei udało się ocalić obraz Matki Bożej Pocieszenia. Tomasz Grzelak został skierowany do pracy w gospodarstwie (ofiarowanym zgromadzeniu) w Raczynie, a wiosną 1941 roku wywieziono go na Pomorze, gdzie pracował do końca wojny. W dniu 7 marca 1940 roku Franciszek Figura został wikariuszem w Skomlinie, a od lutego 1941 roku Józef Drzazga administrował parafią w Wieluniu po rezygnacji Wincentego Przygodzkiego z probostwa.

W gronie aresztowanych kapłanów w listopadzie 1939 roku znaleźli się także księża: Stanisław Chudy, Marcin Łochocki i Romuald Szczeciński, którzy po zwolnieniu musieli opuścić Kraj Warty. Natomiast księża: Jan Wujek, Marian Łosoś i Mieczysław Skoblewski zostali wysłani do obozów koncentracyjnych. Księża Józef Drzazga i Franciszek Deja do 1941 roku mieszkali w klasztorze, a następnie zostali z niego usunięci i pozostali w mieście, odprawiając Msze Święte bez szat liturgicznych za zgodą biskupa Teodora Kubiny. Także w tym czasie organizowali w mieście pomoc duszpasterską dla potrzebujących, mianowicie podczas nocnych przepustek udzielanych przez władze niemieckie. W 1944 roku Franciszek Deja został powołany do wojska do pracy w szpitalu. Po wędrówce po Polsce, Rumunii, Węgrzech i Austrii uciekł i zajął się duszpasterstwem w diecezji poznańskiej. Józef Drzazga był sekretarzem przy radcy szkolnym w Wieluniu, od 1943 roku thumaczem dla Rosjan i Francuzów w obozie w Inowrocławiu, a następnie znalazł się w niewoli rosyjskiej (do października $1945 \mathrm{roku})^{77}$.

Po zakończeniu drugiej wojny światowej prowincjał Antoni Kuczera dokonał benedykacji kościoła. Jako jeden z pierwszych, powrócił do Wielunia Stanisław Chudy, a Witold Drzewiecki przybył w dniu 20 kwietnia 1945 roku. Ponadto do konwentu wieluńskiego należeli bracia: Stanisław Jakus i Franciszek. Pierwszy z nich w styczniu 1946 roku wyjechał do domu zakonnego w Szczytnej, a drugi po zlikwidowaniu domu zakonnego w Wieluniu do Bąblina. Stanisław Chudy w tym czasie wyjechał do Gliwic. Ze względu na ogromne straty materialne prowincjał Antoni Kuczera podjął decyzję o sprzedaży klasztoru, a raczej odstąpieniu go diecezji częstochowskiej wraz z zaciągniętym długiem w wysokości tysiąca dolarów, które zostały pożyczone od pewnej dobrodziejki (zgromadzenia) z Ameryki Północnej. W imieniu biskupa Teodora Kubiny spłaty należności dokonywał Józef Pruchnicki, który został proboszczem w Wieluniu.

${ }^{77}$ AMSFP, brak sygn., T. Dusza, 50 lat działalności Polskiej Prowincji Misjonarzy św. Rodziny, s. $279-283$. 
Oficjalne przekazanie klasztoru nastąpiło w czerwcu 1946 roku przez prowincjała Antoniego Kuczerę i rektora Witolda Drzewieckiego. Na własność zgromadzenia przeszły: Pieta (Matki Bożej Bolesnej), 5 ornatów, puszka na komunikanty i pozostałe meble. Ponadto Józef Pruchnicki przekazał 10 tysięcy złotych na pokrycie kosztów nowego dachu kościoła i wieży ${ }^{78}$.

Zgromadzenie Misjonarzy Świętej Rodziny zostało przyjęte w Wieluniu przez duchowieństwo i wiernych świeckich z ogromną otwartością i życzliwością. Dzięki obecności dodatkowych kapłanów, których brakowało w tym czasie w powiecie wieluńskim do pełnienia posługi duszpasterskiej, na szerszą skalę rozpoczęło się głoszenie misji i rekolekcji parafialnych, klasztor został odnowiony i udostępniony dla wiernych chętnie przyjmujących w nim sakramenty, a także została zapewniona obsada prefekta wieluńskich szkół powszechnych. Wielu młodych ludzi z całego powiatu i spoza jego granic mogło podjąć naukę w gimnazjum misjonarzy, które służyło nie tylko pogłębianiu wiedzy, ale i rozwijało uczniów religijnie. Zaangażowanie księży misjonarzy owocowało nie tylko rozkwitem klasztoru pod względem materialnym, dzięki czemu był on restaurowany i systematycznie modernizowany, ale przede wszystkim pogłębianiem religijności wiernych z miasta i z całego powiatu oraz rozwojem samego zgromadzenia, które dzięki nowym kandydatom zakładało kolejne domy zakonne. Było to ogromnym wsparciem dla duchowieństwa diecezjalnego, które poza duszpasterstwem zajmowało się szeroko pojętą pracą społeczną i działalnością w różnego rodzaju organizacjach i stowarzyszeniach wspierających mieszkańców powiatu w tworzeniu nowego porządku społecznego. Niestety wybuch drugiej wojny światowej i jej szczególnie dotkliwy przebieg w Wieluniu i okolicy spowodowały ogromne straty, także w klasztorze misjonarzy, a w konsekwencji doprowadziły do zakończenia 25-letniej obecności zgromadzenia w Wieluniu.

\section{The Activity of the Congregation of the Missionaries of the Holy Family in Wieluń}

\section{Summary}

In the new reality, after Poland regained its independence, the authorities of the Congregation of the Missionaries of the Holy Family under took some steps in order to establish a monastery in Wieluń. It happener after the approval expressed by bishop Stanisław Zdzitowiecki in 1920. In the

78 Tamże, brak sygn., J. Gawrych, Kronika Księży Misjonarzy Świętej Rodziny od r. 1935 do 1945, s. 13-14; T. Dusza, Działalność Polskiej Prowincji Misjonarzy Świętej Rodziny. Część II. Lata 1945-1952, Poznań 1992, s. 15. 
following year, the monastery of the former Post-Augustinian Conventin Wielun was taken over by the above-mentioned Congregation. Soon, the pastoral work developed and the rep air work of the mediewal convent started. Missionaries placed particular emphasis on Catechesis, preaching missions and services. A novitiate was established simultaneously to a missionary school an eight-year secondary school for men, which was attended by students from the en tire territory of the district of Wieluń. However, the outbreak of the Second World War disrupted an intensive development of the activity of the Congregation of the Missionaries of the Holy Family and the convent suffered material damage then. In 1946, the convent was handel over to the Diocese of Częstochowa.

\section{Keywords}

Wielun, the Second Polish Republic, the Second World War, the Congregation of the Missionaries of the Holy Family

\section{Słowa kluczowe}

Wieluń, II Rzeczpospolita Polska, druga wojna światowa, Zgromadzenie Misjonarzy Świętej Rodziny

\section{Bibliografia}

\section{Źródła archiwalne}

Archiwum Archidiecezji Częstochowskiej im. ks. Walentego Patykiewicza Księgi biskupie i kurialne sygn. 84, Nauczanie religii w szkołach średnich.

sygn. 89, Akta Diecezjalnego Koła Księży Prefektów w Częstochowie.

Teki Patykiewicza

sygn. AD IV-2, Biogramy.

Archiwum Franciszkanów w Katowicach-Panewnikach

[brak sygn.], Kronika Klasztoru OO. Franciszkanów, czyli Zakonu Braci Mniejszych $w$ Wieluniu 1920-1950.

Archiwum Państwowe w Łodzi

Urząd Wojewódzki Łódzki

sygn. 2532, Statystyka wyznaniowa [1938].

Archiwum Państwowe w Łodzi Oddział w Sieradzu

Akta Miasta Wielunia

sygn. 84, Protokoty Rady Miejskiej miasta Wielunia [1915-1921]. 
Starostwo Powiatowe Wieluńskie

sygn. 276, Wykazy zarejestrowanych stowarzyszeń [1928].

sygn. 337, Sprawy innych wyznań [1928].

sygn. 1844, Sprawy wyznania prawosławnego [1931].

sygn. 1856, Wyznanie ewangelicko-augsburskie [1933].

Archiwum parafii w Kiełczygłowie

[brak sygn.], Kronika nowo powstałej parafii Kiełczygłów od 13 X 1924 r.

Archiwum Zgromadzenia Misjonarzy Świętej Rodziny w Poznaniu

[brak sygn.], F. Napierała, Zgromadzenie Księży Misjonarzy św. Rodziny w Polsce, Kazimierz Biskupi-Bąblin 1955-1956.

[brak sygn.], J. Gawrych, Kronika Księży Misjonarzy Świętej Rodziny od r. 1935 do 1945.

[brak sygn.], T. Dusza, 50 lat działalności Polskiej Prowincji Misjonarzy św. Rodziny, Świder 1984.

[brak sygn.], Teczka personalna ks. W. Drzewieckiego.

[brak sygn.], Teczka XVII-16 Wieluń 1938-1962. Krótki opis Kościoła Księży Misjonarzyśs. Rodziny.

\section{Źródła drukowane}

„Głos Ziemi Wieluńskiej” z 1926 roku.

Katalog kościołów i duchowieństwa diecezji częstochowskiej 1968, red. L. Sokołowski, W. Patykiewicz, J. Walicki, Częstochowa 1968.

Katalog kościołów i duchowieństwa diecezji częstochowskiej 1978, red. J. Związek, Częstochowa 1978.

Katalog kościołów i duchowieństwa diecezji częstochowskiej na rok 1939, Częstochowa 1939. „Kronika Diecezji Kujawsko-Kaliskiej” z lat 1918-1924.

„Kronika Diecezji Włocławskiej” z 1927 roku.

„Niedziela” z lat 1926-1927, 1929, 1931, 1933, 1935.

„Posłaniec Świętej Rodziny” z 1931 roku.

Rocznik diecezji włocławskiej 1938, Włocławek 1938.

„Wiadomości Diecezjalne” z lat 1926, 1931, 1933-1934.

„Zew Misyjny” z 1939 roku.

\section{Opracowania}

Barnhoorn H., Ks. Jan Berthier. Założyciel Misjonarzy św. Rodziny 1840-1906, Katowice 1973.

Dąbrowski M., Grzegorz Moczygęba OFM (1888-1951) - duszpasterz i publicysta franciszkański, „Roczniki Teologiczne” 66 (2019) z. 4, s. 113-125.

Dusza T., Działalność Polskiej Prowincji Misjonarzy Świętej Rodziny. Część 2: Lata 1945-1952, Poznań 1992. 
Dyczewski L.B., Religijność społeczeństwa polskiego w okresie międzywojennym, „Collectanea Theologica" 42 (1972), s. 27-43.

Frątczak W., Kościól rzymskokatolicki we Włocławku w okresie Drugiej Rzeczypospolitej, w: Włocławek. Dzieje miasta, red. J. Staszewski, t. II: Lata 1918-1998, Włocławek 2001, s. 221-254.

Frątczak W., Zdzitowiecki Stanisław Kazimierz, w: Włocławski Słownik Biograficzny, red. S. Kunikowski, t. I, Włocławek 2004, s. 186-187.

Jacewicz W., Woś J., Martyrologium polskiego duchowieństwa rzymskokatolickiego pod okupacja hitlerowska w latach 1939-1945, t. II, Warszawa 1977.

Kęsik K., Kościót katolicki w powiecie wieluńskim w czasie I wojny światowej, Opole 2020.

Kostrzewski P., Represje wobec Kościoła częstochowskiego w tzw. Kraju Warty w okresie okupacji niemieckiej (1939-1945), Częstochowa 2015 (mps w Bibliotece Uniwersytetu Humanistyczno-Przyrodniczego im. Jana Długosza w Częstochowie).

Kostrzewski P., Wojenne losy zakonów i zgromadzeń zakonnych w powiecie wieluńskim w okresie okupacji niemieckiej 1939-1945, „Rocznik Wieluński” 16 (2016), s. 189-208 .

Krasowski K., Biskupi katoliccy II Rzeczypospolitej. Słownik biograficzny, Poznań 1996.

Krupa P., Osoba i życie ks. Jana Berthier, w: „, Cor unum et anima una”. Księga Jubileuszowa ku czci księdza Jana Berthier, Założyciela Zgromadzenia Misjonarzy Świętej Rodziny z okazji 100-lecia jego śmierci, red. A.J. Sobczyk, Pelplin 2009, s. 219-225.

Książek J., Powiat wieluński w latach 1918-1939, „Rocznik Wieluński” 1 (2001), s. 111 $-174$.

Kujawski W., Parafie diecezji włocławskiej. Okres kujawsko-kaliski 1818-1925, Włoclawek 2018.

Latawiec K., Duchowieństwo cerkwi prawosławnych resortu celnego i straży granicznej w Królestwie Polskim w latach 1851-1914, „Res Historica” 37 (2014), s. 199-235.

Łoziński B., Leksykon zakonów w Polsce, Warszawa 1998.

Michalska M., Krzyże żelazne w powiecie wieluńskim, „Polska Sztuka Ludowa” 13 (1959) nr 1-2, s. 54-61.

Misjonarze Świętej Rodziny. 100 lat w stużbie Bogu i ludziom, oprac. M. Bocian, Otwock-Poznań 1995.

Molendowski L., Działalność zakonów męskich na Kaszubach w okresie dwudziestolecia międzywojennego, „Acta Cassubiana” 19 (2017), s. 256-286.

Nadolny A., Polonia holenderska, „Studia Polonijne” 1 (1976), s. 109-138.

Olejnik T., Muzeum Ziemi Wieluńskiej. Dzieje. Zbiory. Działalność 1964-1984, Warszawa-Łódź 1989.

Olejnik T., Czasy nowożytne. Praszka w XIX i XX wieku, w: Nad górna Prosną. Monografia Praszki, red. T. Krzemiński, Łódź 1999, s. 309-367.

Olejnik T., Wieluń polska Guernica, ,, das polnische Guernica”, Wieluń 2004.

Olejnik T., Wieluń. Dzieje miasta 1793-1945, Łódź-Wieluń 2008. 
Olejnik T., Szpital w Wieluniu. Jego dzieje i zniszczenie 1 IX 1939 r. Pierwsza zbrodnia II wojny światowej, Wielun 2020.

Patykiewicz W., Banaszkiewicz E., Obraz Matki Bożej Pocieszenia w kolegiacie wieluńskiej, „Częstochowskie Wiadomości Diecezjalne” 45 (1971) nr 4-6, s. 107-115.

Piwowarski W., Formy duszpasterstwa parafialnego w Polsce Odrodzonej (1918-1939), w: Kościót w II Rzeczypospolitej, red. Z. Zieliński, S. Wilk, Lublin 1980, s. 129-148.

Sobczyk A., Krupa P., W kręgu duchowości świętorodzinnej, Pelplin 2007.

Sobczyk A., Krupa P., Ksiądz Antoni Kuczera (1883-1958). Założyciel Polskiej Prowincji Zgromadzenia Misjonarzy Świętej Rodziny, Pelplin 2008.

Stażewski M., Niemiecka polityka archiwalna na ziemiach polskich właczonych do Rzeszy 1939-1945, Warszawa-Lódź 1991.

Sziling J., Polityka okupanta hitlerowskiego wobec Kościoła katolickiego 1939-1945 tzw. Okręgi Rzeszy: Gdańsk-Prusy Zachodnie, Kraj Warty i Regencja Katowicka, Poznań 1970.

Śmigiel K., Kościól katolicki w tzw. okręgu Warty 1939-1945, Lublin 1979.

Uth G., Szkic historyczno-biograficzny Zakonu Augustiańskiego w Polsce, Kraków 1930.

Widera M., Wspólnoty wyznaniowe w powiecie wieluńskim w II Rzeczypospolitej, „Veritati et Caritati” 12 (2019), s. 661-703.

Widera M., ,, Stowarzyszenie Wychodźców Polskich pod opieka Królowej Korony Polskiej $w$ diecezji czestochowskiej” w parafiach powiatu wieluńskiego, ,Studia Teologiczno-Historyczne Śląska Opolskiego" 40 (2020) nr 2, s. 163-184.

Związek J., Przygodzki Wincenty, w: Polski Stownik Biograficzny, red. E. Rostworowski, t. 29, Wrocław 1971, s. 163-164.

Związek J., Straty diecezji częstochowskiej w okresie okupacji hitlerowskiej 1939-1945, „Częstochowskie Studia Teologiczne” 2 (1974), s. 315-366.

Związek J., Martyrologium kapłanów diecezji częstochowskiej w czasie II wojny światowej, „Częstochowskie Studia Teologiczne” 4 (1976), s. 185-300.

Związek J., Ks. Łosoś Marian (1910-1978), „Częstochowskie Wiadomości Diecezjalne” 53 (1979) nr 4-5, s. 113.

Związek J., Działalność duszpasterska na pograniczu Generalnej Guberni i tzw. ziem wcielonych do III Rzeszy w l. 1939-1945: diecezja częstochowska w okresie okupacji hitlerowskiej, „Saeculum Christianum” 2 (1995) nr 1, s. 39-66.

Związek J., Aresztowanie i męczeństwo kapłanów ziemi wieluńskiej okresie okupacji hitlerowskiej, „Rocznik Wieluński” 2 (2002), s. 5-36.

Związek J., Ks. Edward Kubik (20 IX 1880-2 XII 1940), „Wiadomości Archidiecezji Częstochowskiej" 80 (2006), nr 1-2, s. 137-138.

Związek J., Wspomnienia ks. Józefa Kubicy (1911-1952) o pracy duszpasterskiej w powiecie wieluńskim w okresie okupacji hitlerowskiej, w: Wspomnienia wojenne 1939-1945 księży diecezji częstochowskiej, oprac. J. Kapuściński, J. Związek, Częstochowa 2012, s. 123-155.

Związek J., Ksiądz Józef Pruchnicki i jego czasy (1894-1963), Wieluń 2014. 


\section{Strony internetowe}

http://www.bohaterowiekrajny.krakow.pl/kruzowie-meibk.pdf [dostęp 12.06.2021].

https://misjonarzemsf.pl/wydarzenia-2021/gorka-klasztorna-obchody-100-lecia-msf-w-polsce-22-24-maja-2021 [dostęp 09.06.2021].

https://www.bishopaccountability.org/sites/Patejko_Zbigniew/Polish_Mission_Amsterdam.htm [dostęp 12.06.2021].

https://www.ekai.pl/100-lat-misjonarzy-swietej-rodziny-w-polsce/ [dostęp 09.06.2021]. 